Environmental Cost Accounting in Japan: Two Governmental Initiatives

\section{On the Way to the Top}

In Fragen der Umweltberichterstattung liegt Japan bereits vor den USA und Europa. Jetzt geht es darum, auch bei der eher nach innen gerichteten Umweltkostenrechnung den europäischen und amerikanischen Standard zu erreichen.

Zwei Initiativen vom Umwelt- und Industrieministerium haben hier wichtige Impulse gegeben. Daher lohnt eine genavere Analyse ihres Inhalts sowie ihrer komplementären Rolle.

$\mathrm{T}$

Von Katsubiko Kokubu he Environmental Agency (now the Ministry of Environment: MOE) in Japan published draft environmental accounting guidelines in 1999 and released the final version May 2000 (1). Since then the number of companies which disclose environmental accounting information increased rapidly. Among 1430 companies listed in the first section of the Tokyo Stock Exchange 257 companies published environmental reports and 184 companies disclosed environmental accounting information in the reports (2). This number is not smaller but rather bigger than other western countries.

Why do so many companies disclose environmental accounting information in their environmental reports? This is mainly because the MOE's guidelines voluntarily recommend companies to do so. Furthermore MOE and the Ministry of Economy, Trade and Industry (METI) separately published two environmental reporting guidelines. Both guidelines also require companies to disclose environmental accounting information.

Compared with environmental accounting disclosure, environmental management accounting in
Japan has not yet developed very much. In order to improve the situation, METI launched a committee for environmental accounting in 1999 which consists of academia and industry representatives. Within a three years' project the committee will develop environmental management accounting tools for Japanese companies. The Japan Environmental Management Association for Industry (JEMAI), which is the secretary of this project, is publishing the results of the project in annual reports (3).

Obviously the governmental initiatives of MOE and METI focus on different aspects of environmental accounting. In the following both projects are examined in order to understand the main linkages and differences.

\section{MOE's Environmental Accounting Guidelines}

The key contents of the MOE's guidelines can be summarised in the following three points:

- Environmental accounting system,

environmental conservation costs,

environmental conservation effects and economical effects.
The guidelines indicate two different functions of environmental accounting: an internal function for management and an external function for communication with various stakeholders. However, the actual contents of the guidelines are considered to be more oriented to external reporting, rather than internal management. The media to be used for environmental accounting information disclosure in the guidelines is an environmental report, not a financial report. The environmental accounting is supposed to be completely independent from any corporate financial accounting.

\section{A Comprehensive Approach}

The guidelines classify environmental costs into the following six categories:

1. Environmental conservation cost for controlling the environmental impacts that are caused within a business area by production and service activities (abbreviated as business area cost)

2. Environmental cost for controlling environmental impacts that are caused in the upstream or downstream as a result of production and service activities (upstream/downstream cost)

3. Environmental cost in management activities (management activity cost)

4. Environmental cost in research and development activities (research and development cost)

5. Environmental cost in social activities (social activity cost)

6. Environmental cost corresponding to environmental damages (environmental damage cost). The scope of the guidelines is very comprehensive. However, companies do not have to calculate all cost categories in the first stage, but can choose cost categories relevant for them. Another

Exhibit 1: Format C for environmental accounting information disclosure

\begin{tabular}{|l|l|l|l|}
\hline Category & $\begin{array}{l}\text { Environmental cost } \\
\text { mentation and the effects }\end{array}$ & Investment & Expense amount \\
\hline (1) Business area cost & & & \\
\hline 1) Pollution prevention cost & & & \\
Breakdown 2) Global environmental cost & & & \\
\hline 3) Resource circulation cost & & & \\
\hline (3) Management lower stream cost & & & \\
\hline (4) Research and development cost & & & \\
\hline (5) Social activity cost & & & \\
\hline (6) Environmental damage cost & & & \\
\hline $\begin{array}{l}\text { (7) Other environmental cost } \\
\text { (to be specified) }\end{array}$ & & & \\
\hline
\end{tabular}

\begin{tabular}{|c|c|}
\hline \multicolumn{2}{|c|}{ Environmental effects } \\
\hline Contents of effects & $\begin{array}{l}\text { Index of environ- } \\
\text { mental impact }\end{array}$ \\
\hline $\begin{array}{l}\text { (1) Business area effects } \\
\text { (2) Upper/lower stream effects } \\
\text { (3) Other enrironmental effects }\end{array}$ & \\
\hline \multicolumn{2}{|c|}{$\begin{array}{c}\text { Economical effects associated with } \\
\text { environmental measures }\end{array}$} \\
\hline Contents of effects & Amount \\
\hline Revenue obtained by recycling & \\
\hline $\begin{array}{l}\text { Reduction of cost achieved by } \\
\text { energy conservation }\end{array}$ & \\
\hline $\begin{array}{l}\text { Reduction of waste processing } \\
\text { cost achieved by recycling }\end{array}$ & \\
\hline
\end{tabular}


feature of the classification is that lifecycle thinking is introduced to the classification by distinguishing between category (1) and (2).

The most significant features of the guidelines compared with the former guidelines draft are environmental conservation effects (benefits) and economical effects (benefits) introduced in the environmental accounting system. This revision is to overcome the limitation of the guideline draft, which is unable to clarify how efficiently or effectively environmental conservation activities are implemented.

The guidelines provide three types of formats how an environmental accounting statement can be disclosed:

Format A: environmental cost only

- Format B: environmental cost and environmental conservation effects

- Format C: environmental cost, environmental conservation effects and economical effects (see exhibit 1).

Format $\mathrm{C}$ is the most comprehensive one. When a company discloses environmental accounting information in their environmental reports, Format $\mathrm{C}$ is highly recommended if they can fulfill it.

The influence of the MOE's guidelines for Japanese companies is quite strong. 106 out of 184 companies disclosed environmental accounting information based on the MOE's guidelines in their environmental reports. Only 31 companies employ their own original guidelines. The remaining companies just disclosed only a few items of environmental cost not based on any guidelines (2).

\section{METI's Initiatives}

How to integrate the guidelines into corporate decision making becomes an important issue for Japanese companies that introduce environmental accounting. When management accounting is not developed, financial accounting is utilised for internal management as well. However, since decision making in companies has its own specific purpose such as investment decision, price setting and performance evaluation, the integrated environmental conservation cost calculation system provided by the guidelines cannot sufficiently meet such individual purposes.

In order to solve this problem, it is necessary to develop various environmental management accounting tools. While in Japan environmental management accounting practices have been slowly developed, Japanese companies started to recognise the importance of these tools for internal use. The project of METI mentioned above targets the development of tools of environmental management accounting. In this sense, the MOE's project and the METI's project should be complementary to each other.

\section{New Accounting Tools}

METI's project started in 1999 and has been working on a three year research plan. In the first year, it held discussion from various perspectives including financial accounting, quality costing, life cycle assessment and -costing. It also conducted a research on related programs/tools of other countries mainly in the US/Canada and Europe. The research results were published annually in reports by JEMAI (3).

Based on the outcome of the first year of research, four working groups (WG) were established in the second year to develop tools for specific management purposes. WG 1 is developing tools for environmental capital investment decision making. WG 2 is investigating tools for environmental cost management. WG 3 is going to develop tools for environmental and financial performance evaluation. WG 4 is examining material flow cost accounting and conducting pilot testing within a Japanese company. A new project on life cycle costing starts in the third year. The project will be concluded by March 2002.

\section{Kommunikation - Region - Nachbaltigkeit}

und

\section{Flusseinzugsgebiete: Rückbindung der Wirtschaft an die Natur}

\author{
sind die Themen \\ der Informationsdienste
}

\section{Ökologisches Wirtschaften $1 / 02$ und $2 / 02$}

Wenn Sie potenzielle Beiträge haben, wenden Sie sich bitte an die Redaktion.
As we have mentioned before, since the Japanese environmental accounting practices are much inclined to external disclosure, the METI project should be important to develop the other aspect, the internal use of environmental accounting.

\section{- Concluding Remarks}

Corporate environmental accounting in Japan was accelerated by the MOE's guidelines. The number of companies which disclose environmental accounting information in their environmental report is increasing. Most of them follow the MOE guideline. While the focus of the MOE guidelines is on external disclosure, environmental management accounting should be developed as well. The METI's project plays an important role to develop environmental management accounting tools for Japanese companies.

The Japanese external environmental accounting goes ahead US and European practices, but internal environmental accounting lags behind them. While environmental accounting has been going into the second stage in Japan, the big issue at this stage is to develop environmental management accounting catching up with the external environmental accounting system.

\section{References}

(1) The Ministry of the Environment: Developing an Environmental Accounting System, Tokyo 2000.

(2) Kokubu, K./ Nashioka, E: Environmental Accounting Practices of listed Companies in Japan. Discussion Paper No. 2001-26, Graduate School of Business Administration, Kobe University. Kobe 2001 (in Japanese).

(3) Japan Environmental Management Association for Industry (JEMAI) (ed.): Research of Environmental Business Development and Promotion-Environmental Accounting 1999, Tokyo 2000 (respectively 2000, Tokyo 2001) (in Japanese).

(4) Kokubu, K./ Kurasaka, T.: Corporate Environmental Accounting: A Japanese Perspective. Discussion Paper No. 2001-8, Graduate School of Business Administration, Kobe University, Kobe 2001.

\section{Der Autor}

Katsuhiko Kokubu is Professor of Social and Environmental Accounting at Kobe University and Visiting Researcher at Adelaide University

Kontakt: Graduate School of Business Administration, Kobe University, 657-8501 Japan, Fax 0061-8-8303-4368, 0081-78-882-7148 E-mail: kokubu@rokkodai.kobe-u.ac.jp 
(c) 20I0 Authors; licensee IÖW and oekom verlag. This is an article distributed under the terms of the Creative Commons Attribution Non-Commercial No Derivates License (http://creativecommons.org/licenses/by-nc-nd/3.o/), which permits unrestricted use, distribution, and reproduction in any medium, provided the original work is properly cited. 